\title{
Cosmopolitanism and the Society of Strangers
}

\section{Introduction}

Joseph de Maistre famously claimed that human beings endowed with nothing more than their humanity are nowhere to be found and to all practical intents unimaginable. 'In the course of my life', he said, 'I have seen Frenchman, Italians, Russians, etc.; I even know, thanks to Montesquieu, that one can be a Persian. But as for man, I declare that I have never met him in my life; if he exists, he is unknown to me.' Maistre’s observation provides the basis for sociology: the concept of the human being without social characteristics is too vague to serve as a sociological framework, and is also tainted with a slight odour of enlightenment ideals and rootless individualism (Elias, 1991: 163). Because human beings cannot only be defined by their humanity, but any self-definition has to include sociality, identity is perceived as being dependent on social roles within a local or national group. Humanity cannot be set apart from, let alone against, the social roles through which members can express themselves. It is a sociological claim that 'humanity', as a non-empirical assumption, and sociality are balanced in a stable identity that can only emerge in stable local groups (Wrong, 1961; Berger e.a., 1974: 83-96).

The nameless human being without social characteristics, however, is, in cosmopolitan thought, the starting point, motivation and aim of cosmopolitanism. In its self-definition, cosmopolitanism is an ethos of world citizenship, a way of thinking about the relationship between human beings, and, therefore, a way of treating ourselves and others. In Ulf Hannerz words, cosmopolitanism is the 'willingness to become involved with the Other, and the concern with achieving competence in cultures' (Hannerz, 1990: 239-40). In the midst of cultural diversity and a divided world, cosmopolitanism seeks to recognize human goodness, undeterred by traits that are strange, and is eager, through cultural competence, to understand and appreciate humanity in its strange guises (Nussbaum, 1996; Kateb, 1999; Delanty, 2000). Cosmopolitanism argues that in order to appreciate humanity, the social bonds between locals must somehow become weaker, less binding 
and less partial, and more abstract, universal, indeterminate and virtual, so that the Other can be included (Lasch, 1995; Habermas, 2001: 56; Turner, 2002; Bauman, 2003; McDonald, 2004; Flikschuh, 2004).

This essay seeks to open a sociological discussion of the cosmopolitan characteristics of global society. It is argued that the cosmopolitan inclusion of the Other does not pave the way to a global society in which 'humanity' rules, in which 'the common aims of humankind' prevail over the competitive spirit of rivalry and petty ambition of a global bourgeoisie, but results in a comprehensive legitimation of a borderless society of strangers. My central hypothesis is that the ideas, commitments and activities of cosmopolitanism are directed towards the unlimited inclusion of strangers in the local group, the social categories are transformed in such a way that an all-inclusive society of strangers is established. The structure of this essay is: (1) description of the sociological concepts of 'the stranger', the 'local' and 'the cosmopolitan'; (2) description of two perspectives of cosmopolitanism in a global era; (3) argumentation of how cosmopolitanism is legitimated and established as an ethos for a global era; (4) argumentation of how this ethos leads to a global society of strangers

\section{The stranger in classical sociology}

George Simmel (1950) introduced 'the stranger' in sociological vocabulary as 'the third person' in a triad relationship. Simmel's stranger is a subject from outside who is invited by locals, who are acquainted with the stranger, to settle a dispute between two locals. The stranger is available, as a

judge, mediator or arbiter, for a meeting with the locals in the present situation - a meeting that entirely depends on a local conflict situation that the stranger, as the third person from nowhere, without the mediation of some institution, is able to pacify. The locals attribute prestige to the stranger, which is based on the stranger's intellectuality, confidentiality, social distance and judgement that they need to settle their despite. The stranger's social position offers unique opportunities for developing an objective definition of the situation - a definition that the two locals do not accept from one another, but which they accept from the stranger. 
Simmel emphasizes that the two locals need their stranger in order to settle their own disputes without becoming transfixed in sluggish routine and oligarchic self-indulgence. Therefore the locals are obliged to include the stranger as third person in a triad relationship (Pels, 2000: 37-8; 181-183; 226). The locals in conflict select the stranger themselves, as an esteemed acquaintance who holds credentials for being objective. In the relationship with the locals, the stranger occupies a status position because, as stranger, he does not stay, does not seek to be included in the local group, does not compete with locals, and is able to judge local conflicts from a critical distance, with reserve and without prejudice. Simmel's stranger is not strange and marginalized, but objective and critical which the locals are not.

In contrast with Simmel, Alfred Schütz (1944) developed a typology of the stranger as a marginalized type of person within the local group. Schütz's stranger is not a third person who receives credits from the locals, but someone, a migrant, newcomer, visitor or guest, who struggles to be socially accepted or at least tolerated by the locals and who stays. While Simmel's stranger does not aspire to belong to the locals, Schütz's stranger seeks inclusion in the group. While the locals need Simmel's stranger to settle their conflicts, Schütz's stranger poses a threat to the locals. Schütz's stranger is an intruder, whose objectivity is not appreciated by the locals. The locals do not value the stranger because (s)he stays within the group, and hence becomes a strange local. Schütz's stranger is an outsider who does not share 'the cultural pattern of group life'. The stranger may well learn about the cultural pattern of the locals, yet, for the stranger, this knowledge can never become an integral part of the stranger's biography. The stranger cannot attribute the same meaning to the cultural pattern as the locals do. The stranger is therefore necessarily excluded from the locals' cultural experiences.

Like Simmel’s stranger, Schütz's stranger is also objective, but for different reasons. Simmel's stranger is objective because, as a third person, socialized elsewhere, he remains outside the local situation and does not know the cultural pattern of group life. All the stranger comes to know about the locals is their particular conflict situation that (s)he is asked to define. Schütz's stranger is objective because, being socialized elsewhere, (s)he is forced to acquire the necessary knowledge about local group life in order to be included. Knowing two cultural patterns - the knowledge of acquaintance received at home and the knowledge acquired about the new pattern of the locals - 
Schütz's stranger is able to compare two different situations. Hence, Schütz's stranger is able to assume a critical distance to both cultural patterns, because (s)he realizes, unlike the locals, that cultural patterns are not fixed, but relative entities. Schütz insists that the stranger's objectivity towards the cultural pattern of group life is not a shelter, but 'a field of adventure' or 'a problematic situation itself and one hard to master’ (Schütz, 1944: 506). By knowing about two cultural patterns, Schütz's stranger becomes painfully aware of the necessity of renouncing the old norms of guidance, while realizing that sharing the social norms of the locals does not yet lead to being recognized as one of the locals. As a stranger, (s)he is constantly confronted with the discrepancy between the local situation and the homely world of his or her past. Through this awareness of strangerhood, the stranger not only is a stranger for locals, but also becomes a stranger to the self (Kristeva, 1991).

What lies at the heart of the difference between the strangers of Simmel and Schütz is a different conflict situation: Simmel's stranger is confronted with a conflict between two locals, while Schütz's stranger is in conflict with the locals. A comparison between the two concepts shows that Simmel's stranger is credited with objectivity because the locals need that objectivity to solve their local problems, while Schütz's stranger, though objective, is not credited with objectivity because the locals do not need his or her judgement of the situation. Simmel's stranger is invited by the locals as a passing stranger, who solves their problems, whereas Schütz's stranger is disliked as a marginal person, an intruder, who stays and is a burden for the locals. While the locals arrange their meeting with Simmel's stranger to settle their conflict, Schütz's stranger is not welcomed and yet depends on the locals to be included.

According to Zygmunt Bauman, the social position of Schütz's stranger characterizes the global situation. Prior to the global era, the locals needed to exclude their strangers to maintain their group boundaries and make their identity clear. But when strangers question those boundaries and do not take group identities for granted but compare them, then the local situation, through the eyes of the stranger, is defined as strange. This strangeness is the global situation. In Bauman's words: 'the question is no longer how to get rid of the strangers and the strange once and for all, or declare human variety but a momentary inconvenience, but how to live with alterity - daily and permanently' (Baumann, 1997: 30). 


\section{Cosmopolitanism in classical sociology}

While Simmel and Schütz introduced the typology of the stranger in sociology to investigate triad relationships and the social positions of strangers in groups, the cosmopolitan-local distinction has been part of sociological vocabulary since the writings of Robert Merton (Merton, 1968: 441-474) and Alvin Gouldner (1957; 1958) in the 1940’s and 50's (Hannerz, 1990) and more recently has been used in ethical polemics by Martha Nussbaum (1996; 2002). By distinguishing between the cosmopolitan and the local, they reveal a social conflict within the group, between contrasting interests, values, representations and commitments.

Merton distinguishes between the local and cosmopolitan as two types of influential persons. These two types hold different social positions within the same group. The local holds a social position through participation in the local neighbourhood and the cosmopolitan holds a social position through participation in the larger structures of national society. Like Simmel and Schütz, Merton links social position to objectivity. While Simmel's stranger is granted status through his or her knowledge about mediation, and Schütz's stranger is marginalized by locals through his or her lack of local acquaintances, Merton distinguishes between local and cosmopolitan influences as two different sources and uses of knowledge. The local's influence rests on knowledge of acquaintance, on who (s)he knows, while the cosmopolitan's influence rests, like Simmel's stranger, on knowledge about, on what (s)he knows.

The source of knowledge of acquaintance, which is not open to the stranger because the stranger is excluded from local history, is the local's original conditioning. As Merton's type, the local grows up in the local neighbourhood, reads the local news, knows many friends, meets as many people as possible, and is actively involved in local affairs. The local uses knowledge of acquaintance to acquire a social position in the group, through personal contacts within the structure of the local setting. The source of knowledge about things is study. Cosmopolitans enter some local group as strangers, equipped with special knowledge, credentials and social status obtained elsewhere, outside the local group setting. What matters to them is not the number of people they meet, but the kind of 
people with whom they can share their knowledge about things (Hannerz, 1990: 246). Cosmopolitans are accepted by the locals, because the locals give credentials for their knowledge about things. They need that knowledge, often specialized knowledge, which they do not possess themselves, to develop their own neighbourhoods.

While Merton's typology serves to show different patterns of influence in local neighbourhoods, Gouldner distinguishes between locals and cosmopolitans to reveal two types of attachments within the workplace. While the local is committed to the workplace, colleagues and work floor solidarity (through which knowledge of acquaintance is socially organized), the cosmopolitan is committed to degrees, credentials, profession and career. Local workers value routines, collegiality and interpersonal contacts on the work floor. Because locals value their colleagues, they are inclined to be involved in the internal affairs of the organization, for the benefit of the work floor. By contrast, cosmopolitan workers are more reserved or distanced towards others. They prefer to remain strangers, not be included by locals. They are ready to leave the organization, whenever a better opportunity arises elsewhere, in a distinct place or in a different role. And when they move, they take their knowledge with them.

In the typologies of Merton and Gouldner, the local-cosmopolitan distinction, the cosmopolitan is always included in the local group, playing the role as cosmopolitan within the locality. The cosmopolitan is not like Simmel's passing stranger, who arrives today and leaves tomorrow, but is a temporary, mobile element of the locality itself, whose group membership involves strangerhood and confrontation as well as professional credentials and occupational status. The cosmopolitan is someone who is not limited by the boundaries of the town or workplace, because cosmopolitan knowledge about things and the cosmopolitan's professional career easily extend beyond such local boundaries. It does not matter for the cosmopolitan whether (s)he lives in London, Birmingham or Manchester, or works for IBM, Shell or Philips, as long as the position is satisfactory. The cosmopolitan is flexible and mobile enough to move through localities and jobs, while the local is rooted and fixed in neighbourhoods and workplaces.

As an actual condition of professionals and managers who are plugged into a translocal network of global connections, the cosmopolitan-local distinction as an either/or distinction now 
makes a 'caricature' of complex reality (Roudometof, 2005: 122). In the typologies of Merton and Gouldner, the local and the cosmopolitan are manifestations of knowledge that are limited either by local or national boundaries. Still assuming national boundaries, marked by new events like national magazines, national car manufacturers, radio broadcasting, cinema and national advertisement (see Coleman, 1990: 618), their cosmopolitan type is not committed to common humanity, willing to engage with others, but constitutes a national audience. But in the global era, cosmopolitans have emancipated themselves not only from their neighbourhood roots and their workplace, but also from their national grouping. Locals, on the other hand, are left behind, because their knowledge of acquaintance cannot transcend local boundaries (Vertovec and Cohen, 2003). Outside the neighbourhood and workplace, they know nothing.

\section{Cosmopolitanism in current sociology: the global bourgeois}

In the sociological scholarship of Merton and Gouldner, the cosmopolitan type has been portrayed as a bourgeois, who, as a manager or a professional, transcends local boundaries to improve his position, to move upwards, to new and better places. In the global era, the cosmopolitan not only transcends local boundaries, but also national boundaries. In the global era, the cosmopolitan has more in common with partners in Manhattan, London, Singapore or Hong Kong, than with locals or nationals who are not plugged into a network of global connections (Lasch, 1995). This global network is not a group, but an interconnection of worldwide knowledge about things in management and professions to which locals have no access. Contemporary scholarship suggests that the cosmopolitan-local distinction has become a caricature in the global era, because, deprived of knowledge of acquaintance, locals have lost their influence that is originated in that source. Hence locals become powerless in a world without local borders.

Richard Sennett (1998) argues that if colleagues or neighbours are no longer able to meet in the workplace or the neighbourhood, but move elsewhere, locals lose their knowledge of acquaintance. Sennett suggests that, in the global era, the cosmopolitan controls the local's knowledge of acquaintance. Through reorganizing the workplace, often as interim managers, cosmopolitans have 
divided the locals, forcing them out of their routines and compelling them to move to alternative places where they become strangers. Hence the locals have lost their knowledge of acquaintance, and, correspondingly, their interpersonal influence and collegial attachment. Without knowledge of acquaintance, the locals are thrown back upon themselves, on their own subjectivity, where they are confronted with their own alienation, from which they must dredge up the meaning and stability that they require to exist. When knowledge of acquaintance disappears, cosmopolitans are no longer newcomers within a locally established neighbourhood or workplace, but enter a corroded, fragmented or structure-less living and working condition, that is continuously under construction and which they can influence.

Locals cannot survive without knowledge of acquaintance. The neighbourhood cannot survive without neighbours and the workplace cannot survive without work floor collegiality. When knowledge of acquaintance is destroyed, the local's character corrodes away and a deep uncertainty arises about identity or self-image. Cosmopolitans, on the other hand, do not need neighbours and colleagues. For them, the breakdown of group boundaries opens up new possibilities for re-mapping the social order, in which they rule without local and national restraints. Without the limitations and social control of neighbours and colleagues, it is easier for cosmopolitans to achieve their professional or managerial objectives. As their knowledge does not rest on acquaintances, it is easy for them to relativize the stability, coherence and concreteness of the group.

While the corrosion of knowledge of acquaintance enables cosmopolitans to move successfully through social disorganization and insecurity, their 'built-in identity crisis' (Berger e.a., 1974: 92) enables them to move onwards and speed up mobility - not only physical, but also social, mental and ethical mobility. Though cosmopolitans are constantly surrounded by cultural differences, they do not immerse themselves in these, they do not enjoy them. The globalized cosmopolitan is flexible, not because (s)he attributes meaning to cultural identities, but because (s)he considers cultural differences as superfluous. Cosmopolitans are objective, in the sense that, like Simmel's stranger, they are able to distance themselves from existing loyalties. Being a stranger in all places, the biography of the cosmopolitan's career does not need to adjust to any group or place: the cosmopolitan is now able 
to flexibly adjust his or her knowledge to the global order, without local influences and without local attachments.

Rosabeth Moss Kanter (1995: 23) observes that in the global era, cosmopolitans reveal their knowledge about management and profession through the development of new concepts, new standards of managerial and engineering competence and excellent network connections. While the knowledge of the cosmopolitan type developed by Merton and Gouldner was still limited by national borders (American knowledge), today's globalized cosmopolitans are able to take their knowledge everywhere with them, outside the national structures. As a result, the cosmopolitan's concepts, competences and connections (Kanter's three C's) are universal, in the sense that they transcend all localities. As a result, cosmopolitans, in contrast with locals, are able to gain access to knowledge anywhere in the world (Kanter's three C's are globally recognized) and even develop knowledge of global acquaintances through network management.

For Sennett, the World Economic Forum (WEF) is the ultimate cosmopolitan symbol of the victory over the local. The WEF has all the cosmopolitan traits of the global bourgeois: it is an exclusive global network that is kept at a distance from intruders, including the press, so that the global order can be re-mapped without local influence and attachment that may limit the opportunities of the global bourgeois. Sennett observes that the WEF does not seek to improve the condition of the locals, but, on the contrary, seeks to reinforce its own concepts, competences and global connections. Through exchanging information within global networks (not groups), the global bourgeoisie seeks to extend the possibilities of the cosmopolitans' knowledge within their own multinational corporations and international organizations, without being hindered by concrete relations, established authority structures, traditions and norms.

\section{Cosmopolitanism as an ethos: the world citizen}

In sociological scholarship, cosmopolitanism has not only been criticized as a manifestation of the mentality of the global bourgeois, but it has also been interpreted as a new ethos, suitable for 21stcentury global life (Featherstone, 2002; Roudometof, 2005). Sennett and Kanter have described 
cosmopolitanism in its corporate form, in terms of the victory over the local or the corrosion of the cultural pattern of group life. As an ethos, and this is how cosmopolitanism is defined by its advocates, it indicates the willingness of world citizens to become involved with the Other (Hannerz, 1990). From a world citizenship perspective, the cosmopolitan-local distinction may be valid for investigating influence (Merton), loyalty (Gouldner), or corrosion (Sennett), but such a typology offers a rather limited vision of the moral dimension of cosmopolitanism. In fact, world citizenship positions itself as the ethical antithesis of the cosmopolitan type described by classical and current sociology.

World citizenship seeks to include strangers, through identification with many places and histories in an open-ended global space that spans many local groups (Anderson, 2001; Gutman, 2002). World citizenship seeks to transcend strangeness through giving credit to strangers. It turns against a global bourgeoisie who exploits cosmopolitanism, cosmopolitan concepts, competences and connections - the language of universalism - for their own narrow interests (Arendt, 1968; Hannerz, 1990; Nussbaum, 2002). Claiming to speak from no place, no social position, and no identity except as ‘friend of humanity', world citizenship defines itself as a deliberate attempt to abolish exclusion (Rosenfeld, 2002; Arjomand 2004; McDonald, 2004).

In its original, Stoic meaning, world citizenship is an abstract idea about the essential harmony of humankind in the cosmopolis - the world city of strangers from nowhere. While locals identify the cosmopolis as Babylon, world citizens define the cosmopolis as the common language through which the strangers from nowhere can understand, appreciate one another, and live together under the same laws according to the same norms. The world citizen is the one who has acquired the intellectual wisdom to perceive those universal laws of nature (Heater, 1999: 95-96; 148). By giving priority to universal, cosmic laws before the cultural pattern of group life, the world citizen is intellectually and morally emancipated from group conditioning, and thus de facto a stranger to others, including the parents. World citizens do not belong to a particular group, do not accept the institutions that result from group experiences, but identify themselves with 'humanity' alone. In other words, though a stranger to others, world citizens are not strangers to themselves, but define themselves and others as members of the world community of common humanity (Amin, 2004; Golmohamad, 2004). 
Nussbaum stresses that the invitation to world citizenship is an invitation to lose your friends, neighbours and colleagues - 'an invitation to be an exile' (Nussbaum, 1996: 7). World citizenship means that local influence and attachment to families, neighbourhoods, workplaces, nations and churches must give way to inclusive humanitarian aspirations. To this common end, world citizens deliberately define themselves according to their membership to the world community of all human beings, so that it is no longer the local but the stranger who controls thoughts, sentiments and actions. The world citizen is socialized in such a way that (s)he recognizes common humanity before particular sociality in strangers - the human being before the concreteness or immediacy of brotherhood, sisterhood, fellowship or friendship. This wider identification, grounded on knowledge about humanity, and moral obligations to humanity, in the form of 'cultivating humanity' (Nussbaum, 1996), is called 'cosmopolitan virtue' (Turner, 2002: 47).

Martha Nussbaum holds that in an 'era of global connection', the cosmopolitan ethos has become a moral necessity (Nussbaum, 2002). While the cosmopolitan type of classical sociology emerged, as a national audience, with the event of the national media, Nussbaum's world citizen comes to the fore with the event of the global media, as a global audience. With a global media, corporations and governments can no longer keep atrocities secret, while people, as instant spectators, can no longer feign ignorance as if they did not know about what happens to strangers. Ignorance no longer provides an alibi: to remain silent is to plead guilty. To keep one's conscience clear, cosmopolitanism proposes to cultivate the goodwill of locals or nationals to become engaged with strangers, to cultivate a global sense of responsibility for the fate of strangers in distress, regardless of their group identity or social distinctions.

World citizenship implies the elimination of the 'accident of birth', the undoing of the original local conditioning and transcendence of the restraints of local influence and attachment, for the inclusion of strange intellectuality into the locality. In Nussbaum's curriculum, the stranger is, like Simmel's third person, given credit by the world citizen for her or his specific wisdom and expertise, and derives special status from this. The stranger is welcomed, not as a third person, but as a cosmopolitan teacher to world citizens, who has managed to undo any fixed identity as a Jew, bourgeois or black and remake the self anew again as a world citizen. The stranger teaches the locals, 
on their way of becoming world citizens, to loosen their local attachments, to establish a critical distance towards their own locality, and to assume an intellectual stance of openness toward strangers and strangeness. Transformed into world citizens, locals will be able to stand as naked individuals before the group, stripped off of status, social position, and power, and reveal their nakedness in their very sameness in strangeness (Arendt, 1968: 89) - 'as human beings bound to all other human beings by ties of recognition and concern’ (Nussbaum, 2002: 295).

In sum, as an ethos of world citizenship, cosmopolitanism describes itself as an intellectual attempt to understand the common denominator - humanity - in the worldwide chaos of cultural diversity and competing groups. In its self-definition, cosmopolitanism points to different, strange ways of being human, through giving credit different local philosophies, poetry, prose, music and arts, in order to 'recognize common aims, aspirations, and values and enough about these common ends to see how variously they are instantiated in the many cultures and their histories' (Nussbaum, 1996: 9).

Thus far this essay has put forward and examined different concepts and perspectives of strangerhood and cosmopolitanism. The remainder of this essay seeks to show how cosmopolitanism leads to a borderless society of strangers. In order to answer this question, the following steps are taken (1) how cosmopolitanism legitimates strangerhood; (2) how cosmopolitanism seeks to remap the local and global order for the inclusion of strangers; (3) how all this points at the making of a society of strangers.

\section{The cosmopolitan legitimation of strangerhood}

Auguste Comte held that, after the French Revolution, prior to the global age, all of the old world had been destroyed, including its religion, and that the new, post-aristocratic order needed its own gospel and its own church. This, he found in positivism and the église positiviste, in which the new rulers (the bourgeoisie) serves the nation through science and technology. As a new ethos for a global era, cosmopolitanism holds that the post-national order needs its own gospel that it discovers in 
cosmopolitan teachings of giving credit to strange intellectuality, knowledge of different cultural patterns of group life, and inclusion of others.

As an ethos of world citizenship, cosmopolitanism legitimates the inclusion of strangers by stating that strangers are not strange, deviant or dangerous but have their own human goodness, despite their social characteristics. Cosmopolitanism legitimates this claim by investing humanity with an intense religiosity, in the sense that it elevates humanity to the authority status that the world religions would typically attribute to God or the sacred (Hill, 2000; Berges, 2005). Richard Falk holds that cosmopolitanism is 'an essentially religious and normative undertaking, faith in the unseen, salvation in the unseen, salvation in a world to come, guided by convictions, beliefs, values' (Falk, 1994: 139-40).

Pratap Bhanu Metha argues that the cosmopolitan ethos may 'open new horizons' and 'new criticisms' (Metha, 2000: 623). New horizons are opened when it is discovered that all manifestations of global life, such as cosmopolitan law, world citizenship, cosmopolitan education and cosmopolitan cities, emerge, as Bauman says, from 'the birth act of humanity itself [which] lies in the acceptance of the precept of loving one’s neighbour' (Bauman, 2003: 78). The new horizon is located far beyond the neighbourhood or workplace: it encompasses the whole world, cutting through old limits of time (Smith!!!) and space. The new horizon is opened by technology (global communications), which makes global attachment to strangers possible and it makes global influence possible, to rescue strangers in distress within an all-inclusive global system of shared humanity (Donnelly, 1989: 142).

Through adopting the stranger's view from nowhere, world citizens criticize local practices while not being included in the group. Though world citizens certainly do not believe that such local practices are superfluous, unlike the global bourgeoisie, they do believe that they should be criticized when they are exclusive or hostile to strangers. By forcing their strangers to obey their rules of knowledge of acquaintance, locals, without world citizenship, deny the potential goodness of the stranger. As a potentially good human being, both locals and strangers do not need social control through the cultural pattern of group life, but compassion. Without world citizenship, and by defining themselves in opposition to strangers, locals tend to think of strangers too lowly, as inferiors, which is a guarantee that they will treat their strangers basely. 
Ulf Hannerz, however, is rather critical of how cosmopolitanism legitimates its program for inclusion, observing that cosmopolitanism 'often has a narcissistic streak' (Hannerz, 1990: 240). Cosmopolitanism judges all cultural patterns according to its own idea of humanity, to its own belief in human goodness. Martha Nussbaum (2003), for instance, defines Hinduism as an intellectual tradition of 'pluralism, tolerance and openness' which, thus defined, can be easily reconciled with the cosmopolitan ethos. But when it comes to caste, gender inequality, racism, and the worship of violent gods (Nussbaum identifies Hanuman as 'an aggressive monkey god'), then such exclusive practices are identified as the practices of locals, which are not inherent in the intellectuality of Hindus, but in the sociality of their tribal life. In other words, Nussbaum delegitimizes Hindu group life that violently excludes strangers, but gives credits to Hindu intellectuality. Despite all the extreme cruelty and victimhood that she observes in what she calls 'genocide in Gujarat', she does not criticize the humanity of those involved in mass rapes, tortures and killings, but their exclusive local bonds.

\section{Cosmopolitics for remapping the local order}

Classical sociologists recognized in the cultural pattern of group life, that is, in particular customs, habits, manners, mores, values, folkways, meanings, beliefs, ideas, sentiments, taste, symbols, language and local patriotism, the elements of sociality. They realized that common experiences and shared cultural characteristics, shared memories and a sense of common destiny, only had meaning for locals. If the cultural pattern did not have the same meaning to the stranger as to the locals, then the stranger could only form an 'ethnocentric judgement' of the situation (Summer, 1979) - judging one cultural pattern with the norms of another. This was the problem of Schütz's stranger, who had lost his old norms without being able to become a local by his or her own effort. Simmel's stranger did not have this problem, because he did not seek to know the cultural pattern of the locals, but only tried, upon their invitation, to define a particular conflict situation.

Like the stranger, world citizens cannot objectively immerse themselves in other cultures, or in any case, are not free to do so without regard for the sociality of locals (Kateb, 1999). The criterion for the cosmopolitan definition of the local situation is the degree of openness and hospitability 
towards strangers, while giving credits to their intellectuality, even if the stranger's beliefs seem to contradict the beliefs of the locals. Through 'cosmopolitics' (Cheah and Robbins, 1998) the global order is constructed from below, through intercultural exchange, in which beliefs clash to open new horizons and new criticisms.

Ulrich Beck holds that the clash of beliefs between locals and strangers has ended into total disbelief, in nihilism, in a total rejection of the cultural pattern of group life. According to Beck, it is nihilism that has corroded the European pattern and that has produced the most barbarous exclusion of strangers: the holocaust. Beck does not understand cosmopolitanism as the criticism of cultural patterns, but as a criticism of twentieth century nihilism, of the perversion of the old European values of democracy, liberty and human dignity. Thus understood, cosmopolitanism is the collective criticism of cultural breakdowns: cosmopolitanism is 'a reaction against the traumatic experience of European values being perverted' (Beck, 2003). In Beck’s opinion, cosmopolitanism has become a necessary cultural condition in an age where the possibility of technical extermination of humanity as a whole has come within reach. For the sake of global survival, and not for some ethical ideal, humanity must come to the fore in a global age, well ahead of locality.

John Somerville (1981) illustrates this by recalling how during the Cuban missile crisis, the Kennedy administration seems to have preferred the extermination of humanity to having its local or national interests damaged. While in Turkey it had its own missiles pointed at Moscow, it refused to allow Soviet missiles on Cuban territory, even if this refusal would provoke a nuclear world war. Somerville explains that American locals were powerless to influence national structures and hence could not prevent their government from exterminating humanity. Furthermore, socialized as local patriots rather than as world citizens, Americans were unable to identify their own fatherland as the enemy of humanity. Somerville believes that patriotism, as local attachment to the cultural pattern of group life, has always been bad, strongly related to conquest, racism and narrow-mindedness. But given the global context of advanced technology, patriotism has now become a threat to the very survival of humanity. The good old mores and folkways (cowboys) that once bound the Americans in their battles against the Red Indians, have now become destructive to the whole of humanity. Hence cosmopolitanism is not so much an ethical ideal, but an urgent political necessity. 
While the patriotism of the Kennedy administration had been a virtue within the cultural group, it had been a vice outside the locality of America. Within the cultural group, patriotism was a virtue, because it transformed the brutal instinct of self-love into the attachment to the cultural pattern, so that locals were less concerned about themselves than about their fellow locals (MacIntyre, 1995). Local attachment do not need to clash with the attachment to humanity (Hill, 2000; Turner, 2002), but during the Holocaust and during the Cuban missile crisis, the attachment to the local did not extend to the attachment to humanity. Outside the cultural pattern of group life, locals could hardly identify themselves with strangers who were always rather dissimilar, with whom an immediate, concrete relationship had never been intimate, because they could not share their histories.

Martha Nussbaum finds in the attachment to the cultural pattern of group life nothing but the one of 'a tough old soldier', who 'favours a highly disciplined patriotic regiment, with lots of memoriation and not much room for questioning'. Attached to the cultural pattern, locals 'have difficulty understanding people different from themselves, whose imaginations rarely venture beyond their local setting' (Nussbaum, 2002: 302). When the cultural pattern is so powerful an influence on locals, the stranger appears strange, or even hostile, to locals. The cosmopolitan opening of the patriotic mind means transcending local attachment to the cultural pattern of group life in such a way that the cultural pattern is nothing more to patriots than it is to strangers.

\section{Cosmopolitics for remapping the global order}

When Merton and Gouldner constructed their cosmopolitan types in the 1940s, what they had in mind was a type of influential and disloyal person who, with mobile knowledge about things, is able to operate within the larger structures of the nation-state, transcending the limits of local neighbourhoods and workplaces. Merton and Gouldner could not imagine a group larger than the nation-state. In their eyes, the most abstract form of social cohesion was the nationality that ties cosmopolitans and locals together in a common political membership or citizenry. When global processes cut through the borders of the nation, the inclusion of strange ideas, objects and images are experienced, imagined, 
consumed and fantasized, so that strangerhood and friendship above the nation becomes a social reality for many (Skrbis e.a., 2002: 121).

Cosmopolitanism introduces itself as a political project, an alternative to nationalism, urging nation states to adopt a post-nationalist model of ‘world society’ (Meyer e.a, 1997). In the pre-global era, cosmopolitan intellectuals insisted on 'the near-pathological character of nationalism, its roots in fear and hatred of the Other, and its affinities with racism' (Anderson, 1991: 141). Now that global processes cut through the borders of the nation, cosmopolitanism insists that nationality no longer binds citizens. Because citizens are no longer attached to the national pattern of group life, political bonds can no longer be established through nation-building. To bind citizens in a global era, nationstates must legislate 'cosmopolitan law' that aims at the inclusion of strangers in the political group (Habermas, 2001; Beck, 2002; Cohen, 2004).

Cosmopolitanism denies nation-states the right to exclude strangers and to act on behalf of its own national interests that are considered to be too narrow. As cosmopolitanism grants political priority to the inclusion of strangers above national and political unity, it rules out the possibility of national enemies. As a result, cosmopolitan law forbids nation-states waging war against perceived political enemies. Cosmopolitan law grants the nation-state the use of its powers against the enemies of humanity. But since all human beings belong to humanity, the enemy of humanity must be degraded to the category of bestiality or insanity. Those who commit 'crimes against humanity' are therefore not really human or have not really developed their human potential for goodness.

Hence, cosmopolitanism’s strongest critic, Carl Schmitt (1963), believes that cosmopolitanism aims at abolishing the 'political' in nation-states. According to Schmitt, nation-states need the presence of enemies in order to establish political bonds and constitute a political unity. According to Schmitt, in the political world there are only those who have established a political bond (citizens). Those who are excluded from the political bond are defined as enemies. As the stranger is not included in the citizenry, (s) is turned into an enemy. Schmitt criticizes cosmopolitanism for abolishing the enemy in the name of common humanity - hence weakening the political bonds between citizens. (Cohen, 2004). By subjecting nation-states to an 'overarching cosmopolitan legal framework' (Held, 
2003: 521), the meaning of citizenship is reduced from the building of political bonds to the administration of human needs.

Cosmopolitanism argues that the political role of nation-states has changed with the birth of the global era, in the sense that the purpose of citizens is no longer to establish political bonds and bring about their own good life, but to loosen their bonds to rescue those that have been conquered the victims. Political groups must adapt to the global reality of diaspora, genocides and refugees. In the global era, nation-states must, in the name of humanity, open a new horizon for 'saving strangers' (Wheeler, 2003). In the global era, the cosmopolitan ethos states that the new role of nation-states is borderless inclusion and humanitarian control. In sum, cosmopolitanism's political argument is that in the global era, the legitimacy of nation-states exclusively rests on rendering service to humanity and its goodwill to continue doing so, without regard for political unity, balance of power or political interests (Ignatieff, 2000).

\section{The cosmopolis}

Cosmopolitanism does not seek to destroy political unity, but rather to extend political unity from the nation to a global scale, so that all strangers are included in that unity. Cosmopolitanism seeks a borderless political unity, in which all strangers, no matter their nationality, are, as an end in itself, politically included as citizens - as world citizens. This global political unity or world polity is the cosmopolis (Toulmin, 1990; Heater, 1999) or cosmocracy (Keane, 2003). The cosmopolis is based on the 'model of the world society' (Meyer e.a, 1997), of the 'world as a whole' and 'awareness of the "global”' (Szerszynski and Urry, 2002). The world polity is not patterned on a 'cosmopolitan model of democracy’ as developed by Daniele Archibugi and David Held (Archibugi and Held, 1995; Held, 2003; Archibugi, 2004). Their 'cosmopolitan model of democracy' is based on international cooperation between sovereign powers and institutionalized in social forms like international treaties and supranational institutions. Political groups like the European Union are not borderless, but establish their own 'fortress' for their own members. Cosmopolitanism seeks to sack the fortress (Benhabib, 2002). 
The world polity is not established through international treaties, but through global recognition of 'sameness' in strangeness' - through detecting common humanity in particular strangers (Arendt, 1968: 81-2). Stephen Toulmin (1990) argues that, in a divided international society of sovereign powers, the world polity functions to reconcile locals and strangers in a common political and ethical purpose. While nation-states and international systems of governance may include strangers through the legislation of cosmopolitan laws, the cosmopolis includes strangers through the legislation of cosmic laws. According to Toulmin, the very project of modernity is the scientific discovery of cosmic laws, through geometry and physics. The lingua franca of the cosmopolis is not Latin or English, but the language of science.

Jacques Derrida (1997) defines the cosmopolis as a safe haven for strangers, receiving them as neighbours and extending local and national resources to them. Strangers are included in the cosmopolis through hospitality. In other words, the influx of refugees and immigrants as such does not constitute the cosmopolis: the cosmopolis is a powerful identification with the stranger, organizing local life around the theme of the stranger. Ash Amin (2004) suggests that the borderless inclusion of strangers indicates the ongoing interaction between locals and strangers. For Amin, the cosmopolis becomes rooted in the locals' self-understanding, when they are able to transgress all group boundaries, in order to be continuously on the path with strangers, as dislocated nomads and strangers to themselves, of always becoming new persons.

Friedrich Meinecke (1970) recognizes in the cosmopolis an ethical ideal of justice as unlimited inclusion with dangerous political consequences. According to Meinecke, in its political form, cosmopolitanism ultimately points at borderless imperialism. Instead of unlimited inclusion of strangers in the world polity, the establishment of the cosmopolis is the conquest of the world by strangers who break down the political bonds of citizens. Meinecke believes that the worldwide legislation of cosmic laws, valid for universal humanity, does not so much include strangers as destroy those laws that place limits on unlimited and uncontrolled ambitions. Cosmic laws, once discovered, fail to provide compelling arguments against cosmopolitan pretensions becoming political. Without limits, the cosmopolis would not be a political world community, but an empire of strangers, a strange legion, or an imperial administration of the stranger's needs. 
In a similar vein, Alasdair MacIntyre argues that in its political form, the cosmopolitan ethos displaces local, subsidiary authorities and intermediary institutions, which in effect is an invitation of imperial power politics of strangers (MacIntyre, 1981: 158). According to MacIntyre, cosmopolitics of unlimited inclusion within the cosmic order and the inclusion of strangers in local groups are incompatible because cosmopolitics, in his opinion, destroys the local groups; and hence leaves no space for locals to pursue their own ends. In the concept of the cosmopolis, the notion of telos is abandoned for universal inclusion. In MacIntyre's view, the cosmopolis fails to recognize and acknowledge a fundamental conflict between different political and moral alternatives. Unlimited inclusion implies that different political and moral forms are deemed to have similar substances, pursuing similar ends - the common end of humanity - and this is what MacIntyre denies.

In sum, critics hold that the problem of cosmopolitics lies in its subjection of different political and moral forms to its own ethical end - to its own justice as borderless inclusion and to its own rationality as a stranger's view from nowhere (Harris, 2003). The critics of cosmopolitanism believe that adherence to cosmic laws or membership in the world polity does not so much lead to the inclusion of strangers as to the corrosion of local life. And a life, including a global life, can only be lived in some locality, even if that locality is globalized.

\section{Concluding remarks: the society of strangers}

With the globalization of national societies, cosmopolitanism has now become 'something of an urgent reality’ (Arendt, 1968: 82) and 'an actual social condition of many today’ (Mazlish, 2005: 106). Even though humanity, as a reference for the we-identity, is still a blank area on the emotion maps of the many, local groups are increasingly confronted with a widening of identification with strangers and the strange. Such a global identification, as an empirical reality of strangerhood and strangeness, gives way to more inclusive identities than the ties of kinship, nationality and ethnic identity were once able to provide, for the appreciation of the underlying unity of all humankind (Meyer e.a., 1997; Calhoun, 2002). 
As an ethos for the global era, cosmopolitanism delegitimizes essentialist identities that are always group-related, relativizes the locals' struggle for survival in particular social contexts, and subdues local attachments to a higher purpose, that of unlimited attachment to humanity. The cosmopolitan challenge is to develop the intellectual ability to take a distance from their cultural pattern of group life and detach themselves from their old selves, their old cultural patterns, in order to understand themselves as human beings in themselves - without knowledge of acquaintance. In the borderless society of strangers, the distinction between locals and strangers, locals and cosmopolitans, friends and enemies, civilization and barbarism, and the West and the Rest is abolished: cosmopolitanism invites each human being to become friends of humanity and strangers to others.

Cosmopolitanism stresses that in the era of global interconnections, human beings are expected to live, survive or flourish without local, immediate, concrete and exclusive bonds. Cosmopolitanism is a deliberate attempt to make space for strangers, to have world citizens rule in the cosmopolis. Ignorance and fear of strangers is a lack of the will to be part of the world. Such a attempt, however, fails to do justice to classical and current sociology. If humans would be different, they might have been able to become world citizens, like Stoic sages, but given empirical reality, as investigated by the social sciences, world citizenship seems a sociological, psychological, political and economic impossibility for most humans.

The urgent question is, therefore, not whether world citizenship could be attained by many (and not only by the sages), or how 'humanity' could be cultivated, but whether a global society of strangers is possible without collapsing into global violence and servitude. Classical sociologists observed that when locals fail to observe their cultural pattern, one local does not know what to think or expect from the other: trust fades away and hence they become strangers. Without knowledge of acquaintance, locals do not yet define themselves as cosmopolitan, but rather risk becoming victims of anomie and alienation. The future of humanity in a global era seems rather to depend upon the intensity of social control - including the control of the primitive fear of strangers. If this is a sociological truth, then the society of strangers might be like a collective experience of powerlessness, manifested in feelings of personal meaninglessness, loneliness, mistrust, insecurity and anxiety (Giddens, 1991; Bauman, 2003). 
Psychologically, strangerhood seems too hard to bear. When locals become strangers to themselves and to others, and no longer know who they are or who they are to become, no relationship between strangers can be established that would allow the effort of self-definition. It goes without saying that this condition of loss of integrative meaning, which is the essential ordeal of cosmopolitanism, is psychologically hard to bear. For this reason, a longing for the reintegration of local groups and the resistance against strangerhood, through nostalgia, protest, terror and hope, is one of the most powerful realities of globalizing societies (Mazlish, 2005; Roudemetof, 2005).

\section{References}

Amin, Ash (2004) 'Multi-Ethnicity and the Idea of Europe', Theory, Culture \& Society 21 (2): 1-24.

Anderson, Amanda (2001) The Powers of Distance: Cosmopolitanism and the Cultivation of Detachment. Princeton: Princeton University Press.

Anderson, Benedict (1991) Imagined Communities: Reflections on the Origin and Spread of Nationalism. London: Verso.

Archibugi, Daniele and Held, David (eds) (1995) Cosmopolitan Democracy: An Agenda for a New World Order. Cambridge: Polity Press.

Archibugi, Daniele (2004) ‘Cosmopolitan Guidelines for Humanitarian Intervention’, Alternatives 29: $1-21$.

Arendt, Hannah (1968) Men in Dark Times. New York: Harcourt Brace.

Arjomand, Saïd Amir (2004) 'Social Theory and the Changing World: Mass Democracy, Development, Modernization and Globalization’, International Sociology 19 (3): 321-353.

Bauman, Zygmunt (1997) 'The Making and Unmaking of Strangers', in: Postmodernity and Its Discontents. Cambridge: Polity Press.

Bauman, Zygmunt (2003) Liquid Love: On the Frailty of Human Bonds. Cambridge: Polity Press. Beck, Ulrich (2002), 'The Cosmopolitan Society and Its Enemies', Theory, Culture and Society 19 (1): $17-44$ 
Beck, Ulrich (2003) 'Understanding the Real Europe’, Dissent 50 (Summer).

Benhabib, Seyla (2002) ‘In Search of Europe’s Borders’, Dissent 49 (Fall).

Berges, Sandrine (2005) ‘Loneliness and Belonging: Is Stoic Cosmopolitanism Still Defensible?’ Res Publica 11 (1): 3-25.

Berger, Peter, Berger, Brigitte and Kellner, Hansfried (1974) The Homeless Mind: Modernization and Consciousness. New York: Vintage Books.

Calhoun, Craig. (2002) 'Imagining Solidarity: Cosmopolitanism, Constitutional Patriotism, and the Public Sphere’, Public Culture 14 (1): 147-171.

Cheah, Pheng and Robbins, Bruce (1998) Cosmopolitics: Thinking and Feeling beyond the Nation. Indianapolis: University of Minnesota Press.

Cohen, Jean (2004) 'Whose Sovereignty? Empire versus International Law’, Ethics and International Affairs 18 (3): 1-24.

Coleman, James S. (1990) Foundations of Social Theory. London: The Belknap Press of Harvard University Press.

Delanty, Gerard (2000) Citizenship in a Global Age: Society, Culture, Politics. Buckingham: Open University Press.

Derrida, Jacques (1997) Cosmopolites de Tous les Pays, Encore un Effort! Paris: Galilée.

Donnelly, Jacques (1989) Universal Human Rights in Theory and Practice. London: Cornell University Press.

Featherstone, Mike (2002) ‘Cosmopolis: An Introduction’, Theory, Culture \& Society 19 (1-2): 1-16.

Flikschuh, Katrin (2004) 'The Limits of Liberal Cosmopolitanism’, Res Publica 10 (2): 175-192.

Golmohamad, Muna (2004) 'World Citizenship, Identity and the Notion of an Integrated Self', Studies in Philosophy and Education 23: 131-148.

Gouldner, Alvin W. 'Cosmopolitans and Locals: Toward an Analysis of Latent Social Roles I', Administrative Science Quarterly 2/3, 1957: 281-306

Gouldner, Alvin W. 'Cosmopolitans and Locals: Toward an Analysis of Latent Social Roles II', Administrative Science Quarterly 2/4, 1958: 444-480. 
Gutman, Amy (2002) ‘Civic Minimalism, Cosmopolitanism, and Patriotism’, in Stephen Macedo and Yael Tamir (eds), Moral and Political Education, pp. 23-57. London: New York University Press.

Habermas, Jürgen (2001) The Postnational Constellation: Political Essays. Cambridge: Polity Press. Hannerz, Ulf (1990) 'Cosmopolitans and Locals in World Culture’, in Mike Featherstone (ed), Global Culture: Nationalism, Globalization and Modernity. London: Sage.

Harris, Lee (2003) ‘The Cosmopolitan Illusion’, Policy Review 118.

Heater, Derek (1999) What is Citizenship? Cambridge: Polity Press.

Held, David (2003) ‘Cosmopolitanism: Taming Globalization’, in David Held and Anthony McGrew (eds.) The Global Transformations Reader: An Introduction to the Globalization Debate. Cambridge: Polity Press.

Hill, Lisa (2000) 'The Two Republicae of the Roman Stoics: Can a Cosmopolite be a Patriot?', Citizenship Studies 4 (1): 65-79.

Ignatieff, Michael (2000) 'Human Rights as Politics and Human Rights as Idolatry', The Tanner Lectures delivered as Princeton University.

Kanter, Rosabeth Moss (1995) World Class: Thriving Locally in the Global Economy. London: Simon and Schuster.

Kateb, George (1999) ‘Can Cultures be Judged? Two Defenses of Cultural Pluralism in Isaiah Berlin’s Work', Social Research 66 (4): 1009-38.

Keane, John (2003) Global Civil Society? Cambridge: Cambridge University Press.

Kristeva, Julia (1991) Strangers to Ourselves. London: Harvester Wheatsheaf.

Lasch, Christopher (1995) The Revolt of the Elites and the Betrayal of Democracy (London: W.W. Norton).

MacIntyre, Alasdair (1981) After Virtue: A Study in Moral Theory. London: Duckworth.

MacIntyre, Alasdair (1995) 'Is Patriotism a Virtue?’, in: Ronald Beiner (ed), Theorizing Citizenship. Albany: State University of New York Press.

Mazlish, Bruce (2005), 'The Global and the Local', Current Sociology 53 (1): 93-111.

McDonald, Kevin (2004) 'Oneself as Another: From Social Movement to Experience Movement', Current Sociology 52 (4): 575-593. 
Meinecke, Friedrich (1970), Cosmopolitanism and the National State. Princeton NJ: Princeton University Press.

Merton, Robert K., Social Theory and Social Structure (New York: The Free Press, 1968).

Metha, Pratap Bhanu. (2000) 'Cosmopolitanism and the Circle of Reason', Political Theory 28 (5): 619-639.

Meyer, John W., Bol, John, Thomas, George M. and Ramirez, Francisco O. (1997) 'World Society and the Nation-State', The American Journal of Sociology 103 (1): 144-181.

Nussbaum. Martha C. (1996) For Love of Country: Debating the Limits of Patriotism. Boston: Beacon Press.

Nussbaum, Martha (2002) 'Education for Citizenship in an Era of Global Connection', Studies in Philosophy and Education 21: 289-303.

Nussbaum, Martha C. (2003) ‘Genocide in Gujarat: The International Community Looks Away’, Dissent 50 (Summer).

Pels, Dick (2000) The Intellectual as Stranger: Studies in Spokespersonship. London: Routledge.

Rosenfeld, Sophia A. (2002) 'Citizens of Nowhere in Particular: Cosmopolitanism, Writing, and Political Engagement in Eighteenth-Century Europe’, National Identities 4 (1): 25-43.

Roudometof, Victor (2005) 'Transnationalism, Cosmopolitanism and Globalization', Current Sociology 53 (1): 113-135.

Schmitt, Carl. (1963) Das Begriff des Politischen.Berlin: Duncker \& Humblot.

Schütz, Alfred (1944) 'The Stranger: An Essay in Social Psychology', The American Journal of Sociology 49 (6): 499-507.

Sennett, Richard (1998) The Corrosion of Character. New York: Norton.

Skrbis, Zlatko, Kendall, Gavin and Woodward, Ian (2002) 'Locating Cosmopolitanism: Between Humanist Ideal and Grounded Social Category’, Theory, Culture \& Society 19 (1-2): 115-136.

Simmel, Georg (1950), 'The Stranger', in K.H. Wolff (ed), The Sociology of Georg Simmel. New York: The Free Press.

Somerville, John (1981) ‘Patriotism and War’, Ethics 91 (4): 568-578. 
Sterling, Richard W. (1958) Ethics In a Worlds of Power: The Political Ideas of Friedrich Meinecke. Princeton: Princeton University Press.

Sumner, William Graham (1979) Folkways. New York:: Arno Press.

Szerszynski, Bronislaw and Urry, John (2002) 'Cultures of Cosmopolitanism', Sociological Review 50(4): 461-81.

Toulmin, Stephen (1990) Cosmopolis: The Hidden Agenda of Modernity. Chicago: The University of Chicago Press.

Turner, Bryan S. (2002), 'Cosmopolitan Virtue, Globalization and Patriotism, Theory, Culture \& Society 19 (1-2): 45-63.

Vertovec, Steven and Cohen, Robin (2003) Conceiving Cosmopolitanism: Theory, Context and Practice. Oxford: Oxford University Press.

Wheeler, Nicholas J. (2003) Saving Strangers: Humanitarian Intervention in International Society. Oxford: Oxford University Press.

Wrong, Dennis (1961) ‘The Oversocialized Conception of Man’, The American Sociological Review 26: 184-93. 